\title{
The Influence of Civil Servants' Attitude on Engagement and Participation in Cost Reduction Policy: A Case of Malaysia
}

Mohamad Hisyam Selamat (Corresponding author)

Faculty of Business, Accounting and Management, SEGi University

Level 10 SEGi Tower, 47810 Petaling Jaya, Malaysia

E-mail: mohdhisyam@segi.edy.my

Foo Kok Soon

School of Business, Singapore Polytechnic, Singapore

E-mail: jksfoo57@gmail.com

Received: May 5, 2020 Accepted: June 2, 2020 Online published: June 11, 2020

doi:10.5296/jpag.v10i2.16969ＵRL: https://doi.org/10.5296/jpag.v10i2.16969

\begin{abstract}
This study examined the influence of civil servants' attitude on engagement and participation in cost reduction policy implementation in Malaysian public organizations. Attitude was divided into two categories, namely, attitude towards leader and attitude towards government. Civil servant engagement in the workplace was treated as the mediating variable. All these values were included in the conceptual framework. Cross-sectional survey was adopted to validate the framework. The sample size for the population of this study was determined at 400. From the analysis it was found that attitude towards leader and attitude towards government influenced participation in cost reduction policy implementation and engagement significantly. Additionally, engagement mediated the relationships between attitude towards leader, attitude towards government and participation in cost reduction policy implementation. Lastly, it was found that engagement influenced participation in cost reduction policy implementation significantly. The practical implications are the discovery of theoretical, personal, and workplace practical best practices for the participation in cost reduction policy implementation in public organizations.
\end{abstract}

Keywords: cost reduction, public organizations, civil servants, engagement, attitude towards 
leader, attitude towards government

\section{Introduction}

The main objective of public organizations is to deliver services to people effectively and efficiently (Othman et al., 2007). Public happiness on service quality, living affordability (high income, low cost of living and house ownership), public integrity (accountability, stewardship and transparency) and economic growth are usually used to measure service effectiveness and efficiency of public organizations (Blanchard, 2011; Jain \& Jeppesen, 2013; Girard \& McIntyre, 2010; Othman et al., 2007; Syed-Ikhsan \& Rowland, 2004). These are the outcomes that public expect from the government spending. However, becoming effective and efficient in fulfilling public needs at lower cost (populace government) is not an easy task. This is because populace policy leads to higher fiscal deficit (Lehar et al., 2014; Othman et al., 2007). Higher fiscal deficit creates negative image amongst investors and credit rating agencies, which ultimately could lower the investment and economic growth. To face this dilemma public organizations have to be more innovative when spending public money, without compromising on service quality.

To be innovative in reducing public spending, however, civil servants must be highly motivated to collectively identify the strategies to reduce public spending without compromising on service quality. The success of cost reduction policy implementation depends on a synergy through effective and efficient teamwork, collaboration and cooperation amongst civil servants (Selamat et al., 2017). This scenario is termed as civil servant engagement (Shuck \& Wollard, 2010; Rich et al., 2010; Macey \& Schneider, 2008; Saks, 2006; Robinson et al., 2004; Kahn, 1990). Thus it is necessary to investigate government cost reduction policy from the perspective of civil servant engagement.

Kahn (1990) defined personal engagement as the 'harnessing of organization members' which refers to the positive psychological conditions that lead employees to invest themselves actively in their work role and organizations. In engagement, a person can express themselves and be engaged psychologically, emotionally and cognitively in a role (Shuck \& Wollard, 2010; Rich et al., 2010; Macey \& Schneidar, 2008; Kahn, 1990). From this definition it can be seen that a sense of engagement is a critical value to motivate civil servants to participate in organizational activities including the implementation of cost reduction policy in the workplace. To develop a sense of engagement amongst civil servants and in turn motivate them to participate in the implementation of cost reduction policy, this research proposed the element of attitude (Min \& Lee, 2009; McMillan et al., 2003; Fishbein \& Ajzen, 1975). In short, attitude (attitude towards leader, attitude towards government) were independent variables, civil servants' engagement was the mediating variable and participation in cost reduction policy implementation was the dependent variable. To complement this continuum, the relationship between civil servants' engagement and participation in cost reduction policy implementation was also investigated.

Fishbein and Ajzen (1975) defined attitudes as learned character to respond to things or actions. In the public sector, critical attitudes amongst civil servants are attitude towards leader and attitude towards government (Selamat et al., 2017). Attitude is needed to overcome 
barriers associated with civil servants' engagement and participation in cost reduction policy implementation in public organizations. Thus it could be said that being equipped with positive attitude towards leader and attitude towards government enables civil servants to be highly engaged in the workplace and thereafter to be actively participate in the implementation of cost reduction policy.

The paper is organized as follows. Next section presents a theoretical justification for every element in the conceptual framework. Section 3 discusses research approach adopted to validate the proposed factors. Finally, a conclusion is presented in the concluding section.

\section{Theoretical Review}

For the theoretical understanding of public organization cost reduction this paper posited that participation in cost reduction policy implementation is based on the concept of attitude and civil servants' engagement. In the following sections a discussion of attitude and civil servants' engagement is offered.

\subsection{Public Organization Cost Reduction and Civil Servants}

Due to negative impact of high deficit rate on the financial system and fiscal strength, a country that has high deficit rate is usually given low rating by the credit rating agencies such as Standard \& Poor, Moody's, and Fitch Group (Alessi, 2012). The country that get poor rating will be imposed higher interest rate by the international financial institutions including companies incorporated in that country. This will affect badly domestic direct investment and foreign direct investment in the country (Blanchard, 2011). Low investment will reduce economic growth and in turn increase unemployment rate in the country (Blanchard, 2011). This is the scenario that every government in the world, including Malaysia, is trying to avoid. Thus reducing expenditure to achieve good ratings through balanced budget or lower deficit rate is a must for every country.

To reduce public expenditure, however, civil servants must have a motivation to share knowledge and ideas on strategies to reduce public spending without compromising on service quality, living affordability, public integrity and economic growth matters because those knowledge and ideas are tacit in nature. The knowledge and ideas reside in civil servants' mindsets and are continuously developed through their learning process (formal and informal) in the workplace (Beveren, 2002; Churchman, 1971). In turn, they are very private, hard to externalize and hard to share (Amayah, 2013; Selamat \& Choudrie, 2007; Tsoukas, 2002; Nonaka \& Takeuchi, 1995).

The factors of perception, language, time, value and distance create difficulty to externalize and share tacit knowledge (Selamat et al., 2015; Selamat \& Choudrie, 2007; Selamat, 2005; Haldin-Herrgard, 2000). In addition, the inhibitors such as low personal confidence, confusion due to contradicting feeling, lack of enthusiasm and fear inhibit civil servants from seeking information from other colleagues within an organization and in turn dampening discussion activity (Selamat et al., 2017; Amayah, 2013, Selamat \& Choudrie, 2007; Selamat, 2005). These phenomena occur in the workplace due to the gap between superiors and subordinates. The difference in social background such as academic qualification, race, age, 
gender and position is also inhibiting civil servants from participating actively in meeting or discussion (Selamat et al., 2017; Amayah, 2013). The anxiety that other colleagues reject ideas also discourages civil servants from discussing and communicating actively in the workplace (Amayah, 2013; Selamat \& Choudrie, 2007). This is influenced by factors such as low-rank position or lack of necessary knowledge and skills (Amayah, 2013; Selamat \& Choudrie, 2007).

To overcome the above issue this paper argues that civil servants must have a high level of emotional and psychological connection to public organization before they could participate in the process of identifying the strategies to implement low-cost yet high-impact public services. This is termed as civil servants' engagement.

\subsection{Civil Servants' Engagement}

The organizations are becoming concern with the issue of employee engagement as it is a foundation in motivation and productivity (Andrew \& Sofian, 2013; Gubman, 2004; Rothbard, 2001; Kahn, 1990). Management researchers consider employee engagement as a well-developed pivotal strategy and an effective tool to achieve competitive advantage (Albrecht et al., 2015; Bedarkar \& Pandita, 2014; Sakovska, 2012; Rashid et al., 2011). This is evident from previous findings whereby engaging employees positively have an effect on organizational success in terms of economic result, financial performance, reputation, customers' satisfaction, stakeholders' satisfaction, healthy relationship between staffs, staff loyalty and employee retention (Hansen et al., 2014; Andrew \& Sofian, 2013; Zajkowska, 2012; Evans \& Redfern, 2010a, 2010b). On the other hand, disengagement refers to the behaviors of employees that show little commitment and avoidance in involving with the company (Hansen et al., 2014). This scenario occurs because engaged employees incline to work hard and share ideas on how to improve organizational whereas disengaged employees refuse to work hard and share ideas in the workplace (Kadiresan et al., 2016).

Additionally, Wegner (2011) found that engaged employees undertake tasks in accordance with organizational goals, mission and vision. They become more willing to share good attitudes and positive information about their employers with other people. This is because engaged employees trust their organizations and colleagues. Bakker and Demerouti (2007) supported this by saying that engaged employees perform much better compared to those who are not as they are more positive towards their organizations. In short, engaged employees are critical condition for organizational success including public organizations.

To summarize it could be said that the success of cost reduction policy implementation in public organizations relies on the willingness of civil servants to engage in its implementation. Through a process of sharing ideas, evaluating others' ideas and assessing the practicability of those ideas in the meeting the strategies to reduce public spending are identified (Selamat et al., 2017; Saint-Onge, 1996). These strategies represent a synergy that is created through civil servant engagement in the workplace. Thus understanding values that can develop civil servants' engagement and in turn participation in cost reduction policy implementation is paramount. 
2.3 Developing Civil Servants' Engagement and Participation in Cost Reduction Policy Implementation

To develop civil servants' engagement and in turn participation in cost reduction policy implementation this paper proposes the element of attitude. Fishbein and Ajzen (1975) defined attitudes as learned character to respond to things or actions. Attitudes represent a hierarchy of effect from judgments or feeling toward issue, object or person and linked to user behavior (McMillan et al., 2003). Min and Lee (2009) and Simon and Peppas (2004) stated that attitude can be divided into three components which are affective, cognitive or behavioral responses. These three responses are used by previous studies to explain user behavior, such as Jahng et al., (2007), Simon and Peppas (2004), McMillan et al. (2003) and Fishbein and Ajzen (1975). For instance, Simon and Peppas (2004) and McMillan et al. (2003) had used the concept of attitude in the area of marketing to understand the effectiveness of advertisement and found significant relationship between them. This study intends to examine the effect of attitude (attitude towards leader and attitude towards government) on civil servants' behaviors (engagement and participation in cost reduction policy implementation). The following subsections discuss all these values in detail.

\subsubsection{Attitude Towards Leader}

In the context of public organizations, Jain and Jeppesen (2013) stated that there is a positive relationship between management cognitive style (leadership style) and the practice of knowledge management. This is further supported by Girard and McIntyre (2010) and Yao et al. (2007) whereby they found that the awareness of senior management on knowledge management strongly influenced the effectiveness and efficiency of the practice of knowledge management in public organizations. Rhodes et al. (2012) compared the performance of public sector in Brazil, Italy, Portugal, Spain, Ghana, Indonesia and Ireland. From the comparison they found that the most significant factors that influence the performance of public sector are management attitudes and administrative culture. In short it can be said that the behaviors of civil servants in the workplace are strongly influenced by their attitude towards leader. Positive attitude towards leader makes them more committed, dedicated and hardworking in the workplace and vice versa.

In the organizational context, leadership style stimulates close bond between staff members and organizations (Ferres et al., 2004). Ma et al. (2016) and Rich et al. (2010) uncovered that the decision on whether to participate or not in the workplace amongst organizational members relies heavily on the leadership. When undertaking tasks the employees incline to emotionally response to leader which results in the decision making process becomes less influenced by cognition (Min \& Lee, 2009).

To relate the above discussion to this study, civil servants will accept the need to cut office expenditure if they have positive perception towards leader including Prime Minister - the one that introduce cost reduction policy. Positive perception towards leader inculcates a sense of engagement amongst civil servants and motivates them to take part in cost reduction policy implementation (identify the strategies to reduce public spending without compromising on service quality, living affordability, public integrity and economic growth matters). Thus the 
elements of attitude towards leader, civil servants' engagement and participation in the implementation of cost reduction policy are included in this research conceptual framework. This leads to the following hypotheses:

H1a: There is a relationship between attitude towards leader and participation in cost reduction policy implementation amongst civil servants

H1b: There is a relationship between attitude towards leader and engagement amongst civil servants

\subsubsection{Attitude Towards Government}

Democratic system means that the government is elected by the people including civil servants during the Election Day. In other words, civil servants have right to favor one political party than other political parties. If the party that they support fails to form a government those civil servants usually like to criticize and condemn the government in the office and like to quarrel with other colleagues that favor the current government when discussing one government agenda. This could lower the productivity and performance of public organizations eventually (Rhodes et al., 2012). Thus managing political tension in the office healthily is crucial to every public organization. In short it can be said that the behaviors of civil servants in the workplace are strongly influenced by their attitude towards government. Positive attitude towards government makes them more committed, dedicated and hardworking in the workplace and vice versa.

To relate the above phenomenon to this study, it is argued that positive attitude towards government could make civil servants more engaged towards the organization and in turn more willing to take part in cost reduction policy implementation (identify the strategies to reduce public spending without compromising on service quality, living affordability, public integrity and economic growth matters). Thus it is likely that the relationships between attitude towards government, civil servants' engagement and participation in the implementation of cost reduction policy can be obtained in the practical setting. In turn, the following hypotheses are developed:

H2a: There is a relationship between attitude towards government and participation in cost reduction policy implementation amongst civil servants

$\mathrm{H} 2 \mathrm{~b}$ : There is a relationship between attitude towards government and engagement amongst civil servants

\subsubsection{Mediating Role of Civil Servants’ Engagement}

Another value that is investigated in this research is civil servants' engagement. As determining the best strategies to reduce office expenditure requires active communication between superiors and subordinates and also amongst subordinates, civil servants must be active in externalizing and sharing knowledge and obtaining clarification from other colleagues in the workplace (Selamat et al., 2015; Amayah, 2013; Selamat \& Choudrie, 2007; Nonaka \& Takeuchi, 1995). In other words, the success of identifying the strategies to reduce public spending relies heavily on the encouragement of civil servants to share knowledge 
during the brainstorming meeting. In short, civil servants' engagement has a potential to mediate the relationships between attitude towards leader, attitude towards government and participation in cost reduction policy implementation. Based on this argument, this research proposes the following hypotheses:

H3a: The relationship between attitude towards leader and participation in cost reduction policy implementation is mediated by engagement amongst civil servants

H3b: The relationship between attitude towards government and participation in cost reduction policy implementation is mediated by engagement amongst civil servants

2.3.4 Civil Servants' Engagement and Participation in Cost Reduction Policy Implementation

To complement the above hypotheses this study intends to examine the relationship between civil servants' engagement and participation in cost reduction policy implementation. In turn, the following hypothesis is developed:

H4: There is a relationship between engagement and participation in cost reduction policy implementation

\section{Research Methodology}

The research instrument was developed by the researcher. The questionnaire is illustrated in Appendix A. It was set according to the conceptual framework which investigate the effect of attitude on civil servants' engagement and participation in cost reduction policy implementation. The questionnaires were prepared in order to obtain empirical data which will be used to test the hypotheses given in sections 2.3.1-2.3.4. The questionnaire were amended or modified according to the suggestions given by civil servants. This allowed the questions in the questionnaire to be more relevant along with high reliability and validity. Furthermore, the questionnaire were constructed using back to back translation thus, it consisted of two different languages which are Malay and English that allowed the respondents to provide a more accurate answers.

The respondents of this research were all civil servants that involve in financial and/or accounting activities in all federal government ministries' offices in Putrajaya. Two-stage sampling techniques were adopted in this study, which were non-probability sampling and convenience sampling. Non-probability sampling technique refers to the chance of being choose from the target population's is unknown. This is because, the researchers were unable to determine the exact amount of the target population in Malaysian public organizations. Hence, non-probability sampling are much suitable to be used in this research.

Next, convenience sampling technique was used to select the respondents which were the officers who were free to answer or participate in this research. It is a technique where the sample being chosen from the target population on the basis of their accessibility or convenience to the researcher. Furthermore, according to Sekaran and Bougie (2012), convenience sampling provided the best method to collect information because the preliminary information can be obtained quickly and inexpensive way. It allowed the researcher to investigate based on the research limitation as the researcher able to get help 
from one of the officers who act as the researchers' representative in distributing the questionnaire. Thus, it is much convenient and easy for the researcher to obtain data from quality respondents.

Based on the past researchers, the amount of samples size was deemed to be more than 100 as it provide a more valid result. For example, according to Anderson and Gerbing's (1983) study, the sample size of 100 was sufficient for convergence of 3 or more indicators per factor, but still not sufficient as the suitable amount of sample size should be 150 or above for SEM. This was supported by past researcher such as Hoelter (1983) and Schumacker and Lomax (2004) where the researchers proposed a critical sample size of 200 and above as suitable. Therefore, in this study, the researchers asked the representative to distributed 400 questionnaires evenly across ministries' building in Putrajaya.

\section{Research Findings}

Out of 400 distributed questionnaires, 180 were returned. This resulted in a response rate of $45 \%$. As suggested by Sekaran (2003), a response rate of $30 \%$ is considered adequate for mail survey research. Based on this suggestion, the response rate of this study (45\%) was above the recommended rate. In turn, the findings of this research can be generalized to the population.

\subsection{Profile of Respondents}

The frequency and percentage of each demographic profile are illustrated in Table 1. The reported demographic profiles include gender, age and number of years working in the current public organization.

Table 1. Background of the respondents

\begin{tabular}{lcc}
\hline & Frequency & Percentage \\
\hline Gender & & \\
Male & 102 & 56.7 \\
Female & 78 & 43.3 \\
\hline Age (years) & & \\
$21-30$ & 9 & 5.0 \\
$31-40$ & 40 & 22.2 \\
$41-50$ & 104 & 57.8 \\
$51-60$ & 25 & 13.9 \\
Over 60 & 2 & 1.1 \\
\hline Length of Service (years) & & \\
Less than 5 & 11 & 6.1 \\
5-10 & 52 & 28.9 \\
$10-15$ & 19 & 10.6 \\
15-20 & 20 & 11.1 \\
More than 20 & 78 & 43.3 \\
\hline
\end{tabular}

In this study, male respondents were slightly higher than female respondents. Out of 180 respondents, $102(56.7 \%)$ respondents are male and $78(43.3 \%)$ respondents are female. Majority of the respondents $(\mathrm{N}=104,57.8 \%)$ reported that they were in the age group of "41-50". The second largest group were respondents in the age group of " $31-40 "(\mathrm{~N}=40$, $22.2 \%)$, the third largest group were respondents in the age group of " $51-60$ " $(\mathrm{N}=25,13.9 \%)$ 
and the fourth largest group were respondents in the age group of " $21-30$ " $(\mathrm{N}=9,5 \%)$. The smallest group of respondents $(\mathrm{N}=2,1.1 \%)$ reported that they were in the age group of "Over 60 ". Majority of the respondents $(\mathrm{N}=78,43.3 \%)$ reported that they have worked in the public sector for "more than 20 years". The second largest group were respondents that have worked in the public sector for " $5-10$ years" $(\mathrm{N}=52,28.9 \%)$. This is followed by the respondents that have worked in the public sector for "15-20 years" group $(\mathrm{N}=20,11.1 \%)$.

\subsection{Internal Consistency Reliability}

Composite reliability coefficient was utilized to determine the internal consistency reliability of measures. According to Hair et al. (2011) and Bagozzi and Yi (1988), composite reliability coefficient must be at least 0.70 and above. Table 2 illustrates the composite reliability coefficients of the studied variables.

Table 2. Indicator loading, internal consistency reliability and convergent validity

\begin{tabular}{|c|c|c|c|c|}
\hline $\begin{array}{l}\text { Latent Construct } \\
\text { Indicators }\end{array}$ & $\begin{array}{l}\text { Standardized } \\
\text { Loading }\end{array}$ & $\begin{array}{l}\text { Composite } \\
\text { Reliability }\end{array}$ & $\begin{array}{l}\text { Cronbach's } \\
\text { Alpha }\end{array}$ & $\begin{array}{l}\text { Average Variance } \\
\text { Extracted (AVE) }\end{array}$ \\
\hline $\begin{array}{ll}\text { Cost } & \text { Reduction }\end{array}$ & & 0.943 & 0.927 & $\mathbf{0 . 7 3 7}$ \\
\hline Participation & & & & \\
\hline a1 & 0.853 & & & \\
\hline a2 & 0.858 & & & \\
\hline a3 & 0.927 & & & \\
\hline a4 & 0.892 & & & \\
\hline a5 & 0.911 & & & \\
\hline a6 & 0.689 & & & \\
\hline Attitude & & 0.951 & 0.944 & 0.620 \\
\hline Attitude towards Lead & & 0.951 & 0.937 & 0.763 \\
\hline i1 & 0.903 & & & \\
\hline i2 & 0.910 & & & \\
\hline i3 & 0.918 & & & \\
\hline i4 & 0.843 & & & \\
\hline i5 & 0.803 & & & \\
\hline i6 & 0.860 & & & \\
\hline Attitude towards Govt & & 0.947 & 0.932 & 0.750 \\
\hline j1 & 0.864 & & & \\
\hline j2 & 0.901 & & & \\
\hline j3 & 0.851 & & & \\
\hline j4 & 0.910 & & & \\
\hline j5 & 0.926 & & & \\
\hline j6 & 0.731 & & & \\
\hline Engagement & & 0.939 & 0.932 & 0.631 \\
\hline $\mathrm{k} 1$ & 0.864 & & & \\
\hline k2 & 0.874 & & & \\
\hline k3 & 0.794 & & & \\
\hline k4 & 0.796 & & & \\
\hline $\mathrm{k} 5$ & 0.844 & & & \\
\hline k6 & 0.811 & & & \\
\hline k7 & 0.705 & & & \\
\hline k8 & 0.676 & & & \\
\hline k9 & 0.762 & & & \\
\hline
\end{tabular}

From Table 2 it can be seen that the values of composite reliability coefficient for each variable were in a range of 0.939 to 0.951 , with each of them exceeding the minimum 
acceptable level of 0.70 . This signified satisfactory internal consistency reliability of the measures (Hair et al., 2011; Bagozzi \& Yi, 1988).

\subsection{The Significance of the Path Coefficients of Structural Model-Hypotheses Testing}

The function of examining the significance of the path coefficient of structural model is to test hypotheses. The estimated path coefficients between constructs must have significant value. This is obtained by using bootstrapping method (Hair et al., 2014; Hair et al., 2012; Hair et al., 2011; Henseler et al., 2009). The resulting value is the T-statistic or t-value, Beta and $\mathrm{p}$-value (significance value). When $\mathrm{p}<0.05$ the hypothesis is accepted and vice versa (Hair et al., 2016). The summary for the results of Beta, t-value and p-value is illustrated in Table 3. From p-value the variables that have significant relationship with participation in cost reduction policy implementation and engagement were determined.

Table 3. Structural model assessment

\begin{tabular}{lllllll}
\hline Hypotheses & Relationship & & Beta & t & Sig. & Summary \\
\hline H1a & $\begin{array}{l}\text { Attitude towards leader } \rightarrow \\
\text { reduction participation }\end{array}$ & & 0.199 & 4.695 & 0.000 & Supported \\
$\mathrm{H} 1 \mathrm{~b}$ & $\begin{array}{l}\text { Attitude towards leader } \\
\text { engagement }\end{array}$ & 0.116 & 2.427 & 0.016 & Supported \\
$\mathrm{H} 2 \mathrm{a}$ & $\begin{array}{l}\text { Attitude towards government } \rightarrow \text { cost } \\
\text { reduction participation }\end{array}$ & 0.240 & 4.851 & 0.000 & Supported \\
$\mathrm{H} 2 \mathrm{~b}$ & $\begin{array}{l}\text { Attitude towards government } \\
\text { engagement }\end{array}$ & 0.140 & 2.401 & 0.017 & Supported \\
\hline
\end{tabular}

Firstly, the results in Table 3 reveal that there was a significant positive relationship between attitude towards leader and participation in cost reduction policy implementation $(B=0.199$, $\mathrm{t}=4.695, \mathrm{p}<0.05$ ), hence supporting H1a. Additionally, the results also reveal that there was a significant positive relationship between attitude towards leader and engagement $(B=0.116$, $\mathrm{t}=2.427, \mathrm{p}<0.05$ ), hence supporting H1b. In short, positive attitude towards leader results in high engagement and participation in cost reduction policy implementation. Secondly, $\mathrm{H} 2 \mathrm{a}$ and $\mathrm{H} 2 \mathrm{~b}$ anticipate that attitude towards government is positively associated to participation in cost reduction policy implementation and engagement respectively. As shown in Table 3, there were significant positive relationship between attitude towards government and participation in cost reduction policy implementation $(\mathrm{B}=0.240, \mathrm{t}=4.851, \mathrm{p}<0.05)$ and also between attitude towards government and engagement $(B=0.140, t=2.401, p<0.05)$. Thus $\mathrm{H} 2 \mathrm{a}$ and $\mathrm{H} 2 \mathrm{~b}$ were accepted. To recapitulate it can be seen that attitudes (attitude towards leader and attitude towards government) are strongly related to engagement and participation in cost reduction policy implementation amongst civil servants in Malaysia.

\subsection{Mediation Test and Relationship between Civil Servants' Engagement and Participation in Cost Reduction Policy Implementation}

The summary for the results of Beta, t-value and p-value is illustrated in Table 4. From p-value the mediating role of engagement and the relationship between engagement and participation in cost reduction policy implementation were determined. 
Table 4. Mediation and civil servants' engagement and participation in cost reduction policy implementation results

\begin{tabular}{|c|c|c|c|c|c|}
\hline Hypotheses & Relationship & Beta & t-value & Sig. & Summary \\
\hline $\mathrm{H} 3 \mathrm{a}$ & $\begin{array}{l}\text { Attitude towards leader -> } \\
\text { engagement->participation }\end{array}$ & 0.034 & 2.178 & 0.030 & Supported \\
\hline $\mathrm{H} 3 \mathrm{~b}$ & $\begin{array}{l}\text { Attitude towards } \\
\text { government } \\
\text { engagement->participation }\end{array}$ & 0.041 & 2.162 & 0.031 & Supported \\
\hline $\mathrm{H} 4$ & $\begin{array}{ll}\text { Engagement } & -> \\
\text { participation } & \end{array}$ & 0.292 & 5.412 & 0.000 & Supported \\
\hline
\end{tabular}

From Table 4 it can be seen that engagement mediated the relationship between attitude towards leader, attitude towards government and participation in cost reduction policy implementation. Thus hypotheses $\mathrm{H} 3 \mathrm{a}$ and $\mathrm{H} 3 \mathrm{~b}$ were accepted. It can also be seen that there was a significant positive relationship between civil servants' engagement and participation in cost reduction policy implementation. Thus hypothesis H4 was accepted.

\section{Discussion}

This study uncovered that participation in cost reduction policy implementation was positively and significantly influenced by attitude towards leader. The result implies that civil servants that have positive attitude towards leader are more receptive to cost reduction policy and will participate in its implementation actively. On the other hand, this study uncovered that engagement amongst civil servants was positively and significantly influenced by attitude towards leader in the workplace. The result implies that positive attitude towards leader is a basis for developing civil servants' intention to engage with the organization and in turn participation in organizational activities. These findings are similar to that of previous studies such as Jain and Jeppesen (2013), Rhodes et al. (2012) and Yao et al. (2007). The probable explanation could be the democratic system being practiced in Malaysia. Democratic system means that the leader of the state and federal governments are elected by the people including civil servants. If they like the national leader they will like the whole government machinery and ultimately feel more engaged towards the organization. In turn, such feeling will motivate them to take part in organizational activities including the implementation of cost reduction policy. However, uncontrolled political differences in the workplace are not good. This will inhibit the unity amongst civil servants in the workplace which could reduce the quality of services given to public. Thus top management must play an active role in controlling the tension that arises from political differences amongst civil servants in the workplace.

This study also found that attitude towards government influenced participation in cost reduction policy implementation and engagement amongst civil servants in the workplace. The results indicate that attitude towards government was considered by civil servants as the motivational factor in the participation of cost reduction policy implementation and engagement in the workplace. The result of this research is parallel with Jain and Jeppesen (2013), Rhodes et al. (2012) and Yao et al. (2007). As discussed above, the probable 
explanation could be the democratic system being practiced in Malaysia. Democratic system means that the government of Malaysia is formed by the party that wins the general election. If civil servants like the ruling party they will like the whole government machinery and ultimately feel more engaged towards the organization. In turn, such feeling will motivate them to take part in organizational activities including the implementation of cost reduction policy. However, uncontrolled political differences in the workplace are not good. This will inhibit the unity amongst civil servants in the workplace which could badly affect service delivery to public. Thus top management must play an active role in controlling the tension that arises from political differences amongst civil servants in the workplace.

This study also uncovered that the relationships between attitude towards leader, attitude towards government and participation in cost reduction policy implementation were mediated by engagement amongst civil servants in the workplace. These findings are consistent with previous researches such as Jain and Jeppesen (2013), Rhodes et al. (2012) and Yao et al. (2007). They highlighted attitude towards leader and attitude towards government as a basis for developing civil servants' intention to engage with the organization and in turn participation in organizational activities including participation in cost reduction policy implementation. As discussed above, the probable explanation could be the democratic system being practiced in Malaysia. Democratic system means that the government of Malaysia is formed by the party that wins the general election. If civil servants like the ruling party they will like the whole government machinery and ultimately feel more engaged towards the organization. In turn, such feeling will motivate them to take part in organizational activities including the implementation of cost reduction policy. Nevertheless, this scenario could inhibit the unity amongst civil servants in the workplace which could badly affect service delivery to public. Thus top management must play an active role in controlling the tension that arises from political differences amongst civil servants in the workplace.

Lastly, this study uncovered that there was relationship between engagement and participation in cost reduction policy implementation. The result of this study was consistent with Ma et al. (2016), Selamat et al. (2015), Shuck and Wollard (2010), Rich et al. (2010), Macey and Schneider (2008) and Saks (2006). They found significant relationship between employee engagement and organizational outcome. In this study, civil servants considered engagement as the determinant of participation in cost reduction policy implementation in the workplace. The probable explanation could be the perception amongst Malaysians that regard public agencies as safe and reliable employers in the country. Thus protecting the image of public sector as safe and reliable employer should be given a serious attention by top management in public organizations.

\section{Conclusion}

The objective of this study was to determine whether attitude (attitude towards leader and attitude towards government) enable participation in cost reduction policy implementation and develop a sense of engagement amongst civil servants in Malaysia. In addition, this research also investigate whether civil servants' engagement mediates the relationship 
between attitude and participation in cost reduction policy implementation. It was uncovered that attitude towards leader and attitude towards government enabled participation in cost reduction policy implementation amongst civil servants. Thus public organizations must establish a conducive working culture to reduce tension that arises from political differences amongst civil servants in the workplace. This strategy could increase the acceptance and in turn success of cost reduction policy implementation. It was also uncovered that attitude towards leader and attitude towards government influenced engagement behavior amongst civil servants. Thus protecting the image of public sector as an impartisan employer should be given a serious attention by top management in public organizations. In relation to mediation test, civil servants' engagement mediated the relationship between attitude (attitude towards leader and attitude towards government) and participation in cost reduction policy implementation. This highlights high level of engagement amongst civil servants and need to be maintained by the top management. Finally, it was uncovered that civil servants' engagement enabled participation in cost reduction policy implementation. Thus public organizations must instill engagement value amongst civil servants through appropriate organizational activities, training programs and communication.

Although this study have contributed to public financial management area, several limitations have to be considered. First, the context of this study is limited to civil servants. For future research it is suggested that a comparison is made between civil servants and practitioners. Second, this research conceptual framework was tested and examined from the Malaysian perspective. Thus obtaining feedback from the public sector in other countries is necessary. Third, this research adopted cross-sectional survey for data collection. To gain a broad view on the issues related to public organization cost reduction and civil servants' engagement, a longitudinal study is advised. Last but not least, unit of analysis of this study was an individual whereby civil servants were selected as the respondents. To gain more variance in the analysis, obtaining feedback from all individuals working in the public sector is strongly recommended.

\section{Acknowledgments}

This research was funded by Ministry of Education through Fundamental Research Grant Scheme. Special thanks to all civil servants that had participated in this study.

\section{References}

Albrecht, S. L., Bakker, A. B., Gruman, J. A., Macey, W. H., \& Saks, A. M. (2015). Employee engagement, human resource management practices and competitive advantage: An integrated approach. Journal of Organizational Effectiveness: People and Performance, 2(1), 7-35.

Alessi, C. (2012). The Credit Rating Controversy. New York: Council on Foreign Relations.

Amayah, A. T. (2013). Determinants of knowledge sharing in a public sector organization. Journal of Knowledge Management, 17(3), 454-471.

Anderson, J. C., \& Gerbing, D. W. (1988). Structural Equation Modeling in Practice: A 
Review and Recommended Two-Step Approach . Psychological Bulletin, 103(3), 411-423.

Andrew, O. C., \& Sofian, S. (2013). Individual and organizational factors of employee engagement on employee work outcomes. International Journal of Business and Behavioral Sciences, 3(3), 1-9.

Bagozzi, R., \& Yi, Y. (1988). On the evaluation of structural equation models. Journal of the Academy of Marketing Science, 16(1), 74-94.

Bakker, A. B., \& Demerouti, E. (2007). The job demands-resources model: State of the art. Journal of Managerial Psychology, 22(3), 309-328.

Bedarkar, M., \& Pandita, D. (2014). A study on the drivers of employee engagement impacting employee performance. International Conference on Trade, Market and Sustainability, 133, 106-115.

Beveren, J. V. (2002). A model of knowledge acquisition that refocuses knowledge management. Journal of Knowledge Management, 6(1), 18-22.

Blanchard, O. (2011). Macroeconomics, 5th Edition, New York: Pearson.

Churchman, C. W. (1971). The design of inquiring systems. New York: Basic Books.

Evans, C. A., \& Redfern, D. C. (2010a). How can employee engagement be improved at the RRG group? Part 1. Industrial and Commercial Training, 42(5), 265-269.

Evans, C. A., \& Redfern, D. C. (2010b). How can employee engagement be improved at the RRG group? Part 2. Industrial and Commercial Training, 42(6), 330-334.

Ferres, N., Connell, J., \& Travaglione, A. (2004). Co-worker trust as a social catalyst for constructive employee attitudes. Journal of Managerial Psychology, 19(6), 608-622.

Fishbein, M., \& Ajzen, I. (1975). Belief, attitude, intention and behavior: An introduction to theory and research. Addison-Wesley.

Girard, J. P., \& McIntyre, S. (2010). Knowledge management modeling in public sector organizations: A case study. International Journal of Public Sector Management, 23(1), 71-77.

Gubman, E. (2004). From engagement to passion for work: The search for the missing person. Human Resource Planning, 27(3), 42-46.

Hair, J. F., Hult, G. T. M., Ringle, C., \& Sarstedt, M. (2016). A primer on partial least squares structural equation modelling (PLS-SEM). Thousand Oaks, CA: Sage Publications.

Hair, J. F., Ringle, C. M., \& Sarstedt, M. (2011). PLS-SEM: Indeed a silver bullet. Journal of Marketing Theory and Practice, 19(2), 139-152.

Hair, J. F., Sarstedt, M., Hopkins, L., \& Kuppelwieser, V. G. (2014). Partial least squares structural equation modelling (PLS-SEM): An emerging tool in business research. European Business Review, 26(2), 106-121. 
Hair, J. F., Sarstedt, M., Ringle, C. M., \& Mena, J. A. (2012). An assessment of the use of partial least squares structural equation modeling in marketing research. Journal of the Academy of Marketing Science, 40(3), 414-433.

Haldin-Herrgard, T. (2000). Difficulties in diffusion of tacit knowledge in organisations. Journal of Intellectual Capital, 1(4), 357-365.

Hansen, A., Byrne, Z., \& Kiersch, C. (2014). How interpersonal leadership relates to employee engagement. Journal of Managerial Psychology, 29(8), 953-972.

Henseler, J., Ringle, C. M., \& Sinkovics, R. R. (2009). The use of partial least squares path modelling in international marketing. Advances in International Marketing, 20(1), 277-320.

Hoelter, J. (1983). The analysis of covariance structures: Goodness-of-fit indices. Sociological Methods and Research, 11(3), 325-344.

Jahng, J., Jain, H., \& Ramamurthy, K. (2007). Effects of interaction richness on consumer attitudes and behavioral intentions in e-commerce: some experimental results. European Journal of Information Systems, 16(3), 254-269.

Jain, A. K., \& Jeppesen, H. J. (2013). Knowledge management practices in a public sector organisation: the role of leaders' cognitive styles. Journal of Knowledge Management, 17(3), 347-362.

Kadiresan, V., Mohammed, K. N., Mohamad Mazlan, M. R., Musah, M. B., \& Selamat, M. H. (2016). The influence of human resource practices on employee retention: A case study. International Journal of Human Resource Studies, 6(3), 122-148. http://dx.doi.org/10.5296/ijhrs.v6i3.10093

Kahn, W. A. (1990). Psychological conditions of personal engagement and disengagement at work. Academy of Management Journal, 33(4), 692-724.

Lehar, H., Anas, Y., \& Tey, H. C. (2014). Malaysian Economy. Kuala Lumpur: Oxford University Press.

Ma, B., Liu, S., Liu, D., \& Wang, H. (2016). Job security and work performance in Chinese employees: The mediating role of organisational identification. International Journal of Psychology, 51(2), 123-129.

Macey, W. H., \& Schneider, B. (2008). The meaning of employee engagement. Industrial and Organizational Psychology, 1(1), 3-30.

McMillan, S. J., Hwang, J., \& Lee, G. (2003). Effects of structural and perceptual factors on attitudes toward the website. Journal of Advertising Research, 43(4), 400-409.

Min, J. Y., \& Lee, H. (2009). Getting emotional with the system that mirrors you: Cognitive and affective attitudes towards identity-reflecting information systems. In PACIS. Hyderabad, India. Retrieved from http://aisel.aisnet.org/pacis2009/50

Nonaka, I., \& Takeuchi, H. (1995). The knowledge creating company. New York: Oxford 
University Press.

Othman, O., Ismail, M. S., Syed Ismail, S. S., Saidin, S. Z., Rahim, M. S., Md Saleh, M. S., Samsudin, R. S., \& Mohd Lazim, M. (2007). Public Sector Accounting in Malaysia (1st ed.). Singapore: Cengage Learning Asia.

Rashid, H. A., Asad, A., \& Ashraf, M. M. (2011). Factors persuading employee engagement and linkage of EE to personal and organizational performance. Interdisciplinary Journal of Contemporary Research in Business, 3(5), 98-108.

Rhodes, M. L., Biondi, L., Gomes, R., Melo, A. I., Ohemeng, F., Perez-Lopez, G., Rossi, A., \& Sutiyono, W. (2012). Current state of public sector performance management in seven selected countries. International Journal of Productivity and Performance Management, 61(3), 235-271.

Rich, B. L., Lepine, J. A., \& Crawford, E. R. (2010). Job engagement: Antecedents and effects on job performance. Academy of Management Journal, 53(3), 617-635.

Robinson, D., Perryman, S., \& Hayday, S. (2004). The drivers of employee engagement. Institute for Employment Studies Report, 408. Retrieved from: tinyurl.com/IES-drivers

Rothbard, N. P. (2001). Enriching or depleting? The dynamics of engagement in work and family roles. Administrative Science Quarterly, 46(4), 655-684.

Saint-Onge, H. (1996). Tacit knowledge: The key to the strategic alignment of intellectual capital. Strategy and Leadership Journal, 24(2), March/April, 10-14.

Sakovska, M. (2012). Importance of employee engagement in business environment: Measuring the engagement level of administrative personnel in VUC Aarhus and detecting factors requiring improvement (Unpublished doctoral dissertation). Aarhus University. Retrieved from https://scholar.google.com/

Saks, A. M. (2006). Antecedents and consequences of employee engagement. Journal of Managerial Psychology, 21(7), 600-619.

Schumacker, R. E., \& Lomax, R. G. (2004). A beginner's guide to structural equation modeling (2nd ed.). London: Routledge.

Sekaran, U. (2003). Research method for business: A skill building approach (4th ed.). Danvers, MA: John Wiley \& Sons.

Sekaran, U., \& Bougie, R. (2012). Research methods for business: A skill building approach (6th ed.). Chichester, West Sussex: John Wiley \& Sons, Inc.

Selamat, M. H. (2005). Developing Individuals for Developing Learning-Based Systems (Unpublished doctoral dissertation). Brunel University, UK.

Selamat, M. H., \& Choudrie, J. (2007). Using meta-abilities and tacit knowledge for developing learning based systems: A case study approach. The Learning Organization, 14(4), 321-344. 


\section{Macrothink}

Journal of Public Administration and Governance ISSN 2161-7104 2020, Vol. 10, No. 2

Selamat, M. H., Mat Saat, R., Indra Zuhdi Murat, R., \& Foo, K. S. (2017). Developing civil servants' affective commitment to share knowledge: A case of public organization cost reduction. International Journal of Business and Management, 12(2), 160-170. http://dx.doi.org/10.5539/ijbm.v12n2p160

Selamat, M. H., Selladurai, S., \& Abdul Halim, H. M. (2015). The influence of task accomplishment and attitude on active teaching in Malaysian universities. European Journal of Business and Social Science, 4(1), 35-48.

Shuck, B., \& Wollard, K. (2010). Employee engagement \& HRD: A seminal review of the foundations. Human Resource Development Review, 9(1), 89-110.

Simon, S. J., \& Peppas, S. C. (2004). An examination of media richness theory in product web site design: an empirical study. Info, 6(4), 270-281.

Syed-Ikhsan, S. O. S., \& Rowland, F. (2004). Benchmarking knowledge management in a public organisation in Malaysia. Benchmarking: An International Journal, 11(3), 238-266.

Tsoukas, H. (2002). Do we really understand tacit knowledge? Knowledge Economy and Society Seminar, London.

Wegner, P. M. (2011). The relationship between employee engagement and employee retention in an acute healthcare hospital (Unpublished doctoral dissertation). Walden University.

Yao, L. J., Kam, T. H. Y., \& Chan, S. H. (2007). Knowledge sharing in Asian public administration sector: The case of Hong Kong. Journal of Enterprise Information Management, 20(1), 51-69.

Zajkowska, M. (2012). Employee engagement: How to improve it through internal communication. Human Resources Management and Ergonomics, 6(1), 104-112. 


\section{Appendix A}

\section{Questionnaire Items}

\section{A. Items measuring participation in cost reduction policy implementation}

1. I like the idea of cost reduction

2. Cost reduction policy inspires me

3. I am optimistic with the cost reduction policy

4. I feel happy when implementing cost reduction policy

5. I support cost reduction policy

6. I am enthusiastic about cost reduction policy

\section{B. Items measuring attitude towards leader}

1. I am proud with the current leaders

2. I feel happy working with the current leaders

3. Current leaders inspire me

4. I respect the current leaders

5. I am optimistic with the current leaders

6. I work hard because I like the current leaders

\section{Items measuring attitude towards government}

1. I work hard because I like the current government

2. I feel happy working for the current government

3. Current government inspires me

4. I am proud with the current government

5. I respect the current government

6. I am optimistic with the current government

\section{Items measuring engagement}

1. I exhibit high level of energy while performing a job task

2. I exhibit high mental resilience while performing a job task

3. When I get up in the morning I feel like going to work

4. I am enthusiastic about my job

5. My job inspires me

6. I am proud of the work that I do

7. I feel happy when I am working intensely

8. I am immersed in my work

9. I get carried away when I am working

\section{Copyright Disclaimer}

Copyright for this article is retained by the author(s), with first publication rights granted to the journal.

This is an open-access article distributed under the terms and conditions of the Creative Commons Attribution license (http://creativecommons.org/licenses/by/4.0/). 